\title{
Rainfall, microhabitat, and small mammals influence the abundance and distribution of soil microorganisms in a Chilean semi-arid shrubland
}

Lorgio E. Aguilera ${ }^{1 *}$, Cristina Armas ${ }^{1,2^{*}, \psi}$, Alex P. Cea ${ }^{1}$, Julio R. Gutiérrez ${ }^{1,2,3}$, Peter L. Meserve $^{4,5}$, and Douglas A. Kelt ${ }^{6}$

${ }^{1}$ Departamento de Biología, Facultad de Ciencias, Universidad de La Serena, Casilla 554, La Serena, Chile

${ }^{2}$ Instituto de Ecología y Biodiversidad, Universidad de Chile, Santiago, Chile

${ }^{3}$ Centro de Estudios Avanzados en Zonas Áridas (CEAZA), Casilla 554, La Serena, Chile

${ }^{4}$ Department of Biological Sciences, Northern Illinois University, DeKalb, Illinois 60115, USA; ${ }^{5}$ Department of Biological Sciences, University of Idaho, Moscow, Idaho 83843

${ }^{6}$ Department of Wildlife, Fish, and Conservation Biology, University of California, Davis, CA 95616, USA

*E-mail of corresponding authors: laguiler@userena.cl; carmas@ userena.cl. These authors contributed equally to the paper.

$\Psi$ Current address: Estación Experimental de Zonas Áridas, Consejo Superior de Investigaciones Científicas (EEZA-CSIC), Carretera de Sacramento s/n, 04120 La Cañada, Almería, Spain

Type of article: Research article for the special issue SI Fray Jorge 
Abstract: Patterns in rainfall and soil water availability are considered to be the main drivers governing arid and semiarid ecosystems. While the mechanisms by which water limits aboveground net primary production has been widely explored, few long-term studies have examined interactions between precipitation, soil resources, plant communities, and soil microbial communities; these may be critical to understanding soil biogeochemical cycles and above- and belowground interactions. We capitalized on a long-term biotic manipulation (exclusion of small mammal herbivores from replicate plots) and long-term variation in rainfall to assess how precipitation, small mammals, and shrub cover act directly and interactively to influence the spatial and temporal distribution of soil microorganisms, a key first step to understanding soil biogeochemical cycles. We measured the abundance of arbuscular mycorrhiza (AM), soil fungi, soil bacteria, and soil physicochemical characteristics over 10 consecutive years in a semiarid thorn scrub community in north-central Chile; we sampled two microhabitats (under shrub cover, and in open spaces between shrubs colonized by ephemeral plants), and in plots with or without the presence of native small mammals, the main herbivores in this environment. Annual rainfall ranged widely $(11$ to $356 \mathrm{~mm})$ in this period and was the primary factor affecting abundance of AM root colonization and soil microbes. While the percentage of root length with AM was higher in dry compared to wet years, free-living soil bacteria and fungi were more abundant during wet years. All microorganisms were more abundant in the resource islands beneath the shrubs compared to open microhabitat between shrubs, although the relation between soil biota and the concentration of some particular nutrients was negative. These patterns were modulated by the presence of small mammals, which enhanced root colonization by AM fungi, particularly for ephemeral plants, but which were negatively associated with soil fungi abundance. The abundance of soil bacteria showed a more complex response to the presence of small mammals and was dependent on microhabitat and year. The spatial and temporal heterogeneity of soil resources and the activity of small mammals are important 
modulators of subterranean biotic responses to rainfall, the primary factor affecting soil microbiota abundance in this semiarid ecosystem.

Keywords: ENSO, LTSER, Plant-soil interactions, Mycorrhizal fungi, Soil filamentous fungi, Soil heterotrophic bacteria, Soil yeasts. 


\section{Introduction}

The soil microbial community is a key element underlying ecosystem processes such as organic matter decomposition and carbon and nitrogen cycling (Bardgett and Wardle, 2010). Soil microbiota has a paramount influence on plant performance, plant community diversity, and composition (Barea et al., 2011; Bever et al., 2010; Wardle et al., 2004). Nonetheless, the reciprocal effect also occurs. The composition, abundance, and activity of soil microbial communities not only depends on climate and soil physicochemical properties (e.g., $\mathrm{pH}$, temperature, nutrients, or moisture; Bardgett and Wardle, 2010; Soudzilovskaia et al., 2015), but also is closely linked to plant communities through complex interactions (e.g., Bardgett and Wardle, 2010; Bever et al., 2010). Plants affect the quality and quantity of soil properties, particularly organic resources, and provide the organic carbon required for the functioning of the soil microbial decomposer system and obligate root-associated organisms such as symbiotic mutualists (Wardle et al., 2004). Thus, fluctuations in the biomass of soil and rhizospheric microbial communities and their structure may covary with the structure, composition, and productivity of plant communities (Bardgett and Wardle, 2010; Lozano et al., 2014).

Arid environments are characterized by heterogeneity in rainfall, soil resources, and structure of plant communities, both in space and time (Noy-Meir, 1973). This heterogeneous environment may ultimately affect the composition, distribution, and abundance of soil microorganisms. Plant communities in arid shrublands usually form a mosaic of perennial plant patches interspersed within a matrix of soil with low plant cover most of the year (Aguiar and Sala, 1999). During the rainy and most favorable season, many of these arid shrublands host the growth of an ephemeral plant community (e.g., 
vegetation in Mediterranean and other warm-arid climates such as lowland Chilean deserts or the Mojave or Sonoran deserts of North America; Gutiérrez et al., 2010; Jiménez et al., 2011). This heterogeneity in rainfall and vegetation patterns ultimately produces strong spatial and temporal patchiness in biogeochemical processes and the distribution of soil resources (Austin et al., 2004; Reynolds et al., 1999). Plant patches formed by shrubs or trees and other perennial grasses usually lead to the development of "resource islands" or "islands of fertility" compared to the relatively or temporary infertile soils in areas between shrubs (Reynolds et al., 1999; Schlesinger et al., 1996). Overall, these shrub-resource islands act as points of high biological activity, both for plants (see examples in Callaway, 2007; Pugnaire et al., 2011) and soil microbial communities (Aguilera et al., 1999; Goberna et al., 2007; Hortal et al., 2013), enhancing microbial biomass; C, N, and ATP content; microbial respiration; enzymatic activities; and nutrient cycling associated with the activity of this biota, such as higher $\mathrm{C}$ and $\mathrm{N}$ mineralization rates (Goberna et al., 2007; Hortal et al., 2013).

Another less documented factor that may affect soil microbial communities is the presence of organisms from higher trophic levels, such as herbivores, whose activity (e.g., foraging, digging, defecation or lair construction) affects not only the vegetation but the structure and physicochemical characteristics of soils in deserts (e.g., Kelt, 2011; Whitford, 2002; Whitford and Steinberger, 2010), thus potentially influencing the distribution and abundance of soil microorganisms. Herbivores may also influence the dispersal of soil microbiota. It is acknowledged that mycophagy by mammals can be a key mechanism of fungal dispersal (e.g., Nuñez et al., 2013; Wood et al., 2015), and they may also act as epizoochorus vectors dispersing microbial propagules attached to their fur (Frank et al., 2009; Godfrey, 1957). 
Long-term studies in semiarid environments in north-central Chile have shown that the composition and productivity of ephemeral plant communities is determined largely by the availability of water, which in turn is driven mainly by inter-annual climatic fluctuations associated with El Niño - Southern Oscillation (ENSO) events (Gutiérrez et al., 2010; Jiménez et al., 2011; Meserve et al., 2003). ENSO events in this region comprise irregular oscillations between warm-rainy (El Niño) and cold-dry (La Niña) periods, and these climatic cycles provoke huge variations in plant cover, productivity, and diversity (Gutiérrez et al., 2010; Jiménez et al., 2011). Overall, precipitation, soil water availability, and plant community distribution and dynamics likely influence variation in the density and activity of soil microbial communities, together determining soil fertility and the path and dynamics of biogeochemical cycles at a community level (Austin et al., 2004). However, few long-term studies in arid systems have analyzed how precipitation, plants, and their interactive effects on the spatial and temporal distribution of soil properties may influence the abundance of soil microorganisms, a key first step to understanding soil biogeochemical cycles (Bardgett and Wardle, 2010; Soudzilovskaia et al., 2015) and abovegroundbelowground interactions (Wardle et al., 2004) in these heterogeneous arid environments. We analyzed the long-term role of precipitation, microhabitat, and biotic factors on the abundance of soil microorganisms and soil characteristics in a semiarid shrubland. We distinguished three main functional and taxonomical groups of soil microbiota: bacteria, saprophytic fungi, and arbuscular mycorrhiza fungi (AM), and we analyzed the percentage of root length colonized by the latter. We hypothesized that precipitation, plants, soil resources, and their distribution would play a key role affecting the long-term pattern of abundance of soil microorganisms, and that disturbance by herbivores would modulate this belowground response. We predicted that precipitation would be the main driver of soil 
microbial abundance, and we expected a close positive relation among rainfall, available soil resources, plant cover, and abundance of soil microorganisms. Higher water availability in ENSO years translates to higher primary production (Holmgren et al., 2006; Meserve et al., 2003), enhancing soil organic matter (SOM) and potentially enhancing the mineralization of organic matter (Whitford, 2002). This could increase the availability of SOM and nutrients for microorganisms and plants, respectively. We also predicted that the abundance of soil microorganisms would be higher under shrubs compared to open spaces, as soil resources would be higher under shrubs, particularly in ENSO rainy years. Finally, herbivores in this system are native small mammals, and we expected that these would indirectly affect the abundance of soil microbiota; we anticipated this influence to be greatest under shrub cover where these species are more protected from predation (and hence where they burrow, defecate, and spend more time), but also to an unclear extent in open habitats where their favoured foods grow in wet years (Lagos et al., 1995).

\section{Material and Methods}

\subsection{Study Site}

The study was performed in a Long-Term Socio-Ecological Research site (LTSER) (sensu Anderson et al., 2008) located in a valley ("Quebrada de Las Vacas”, $230 \mathrm{~m}$ elevation) in Bosque Fray Jorge National Park (henceforth "Fray Jorge") in north-central Chile, a World Biosphere Reserve (30³8'S, $\left.71^{\circ} 40^{\prime} \mathrm{W}\right)$. The climate is semiarid Mediterranean, with $90 \%$ of the $127 \mathrm{~mm}$ annual precipitation falling in winter months (May through September). Daily maximum temperatures range from ca. 26 to $28^{\circ} \mathrm{C}$ in summer to 24 to $26^{\circ} \mathrm{C}$ in winter; mean minimum daily temperatures are $10^{\circ} \mathrm{C}$ in summer and 0 to $2{ }^{\circ} \mathrm{C}$ 
in winter. Fog and coastal breezes have a strong ameliorating impact on local climate, particularly in summer (Gutiérrez et al., 2010). Annual rainfall exceeding mean long-term values is usually associated with El Niño - Southern Oscillation (ENSO) events (Gutiérrez et al., 2010), which generally last about one year and occur every 3-5 years. During the period of study (1997-2006) rainfall varied greatly among years and ranged from 11 to 337 mm (Fig. 1): rainfall was lower than average in four of ten years, and ENSO events in 1997 and 2002 resulted in heavy rainfall (330 and $337 \mathrm{~mm}$, respectively). Rainfall was close to average in 2003 and 2005 (80 and 90 mm, respectively). See Armas et al. (2016) and Montecinos et al. (2016) in this special issue for further details on the climate of the study area.

The plant community is characterized as a thorn-scrub shrubland composed mainly of drought-deciduous and evergreen shrubs $2-3 \mathrm{~m}$ in height, and an assemblage of ephemeral plants during the winter-spring growing season (Gutiérrez et al., 2010). The dominant shrub species is the evergreen Porlieria chilensis I. M. Johnst. (Zygophyllaceae, 25-35\% cover), followed by the drought-semideciduous Adesmia bedwellii Skottsb. (Fabaceae, 2.6-5.7\% cover; Adesmia hereafter) and the drought-deciduous Proustia cuneifolia D. Don (Asteraceae, 4.0-9.5\% cover). A comprehensive description of the plant species composition and abundance at the site is provided in Gutiérrez et al. (2010) and references cited therein. Soils are loamy sand with $85 \%$ sand, $8 \%$ silt, and $6 \%$ clay (Aguilera et al., 1999).

A long-term study site was established here in 1989 and the associated experimental design has been maintained for more than 25 years, making this the longest such study in temperate South America (Gutiérrez et al., 2010). This LTSER initially included sixteen $75 \times 75 \mathrm{~m}$ experimental plots $(0.56 \mathrm{ha})$, each separated by at least $50 \mathrm{~m}$. Plots were randomly 
assigned to four biotic treatments (with four replicates each; see details in Kelt et al., 2013), but only two are relevant to this study: these are small mammal exclusions (-SM), and control treatments $(+\mathrm{SM})$, the latter of which enable full access by all species. Control treatments $(+\mathrm{SM})$ had low $(1 \mathrm{~m})$ fencing buried $40 \mathrm{~cm}$ into the ground with $2.5-\mathrm{cm}$ holes at ground level every $2 \mathrm{~m}$ to allow access by all small mammals. The four -SM plots had similar fencing but were designed to exclude some or all small mammals; from 1989-2000 these excluded only degus (Octodon degus), one of the largest and the most abundant small mammal at our site, but from 2001-2006 this treatment excluded all small mammals (for simplicity, we will call degu and small mammal exclusion plots as -SM plots, although they are treated as different treatment levels in the statistical analyses). Differences in small mammal abundance and population dynamics across treatments are presented elsewhere in this special issue (Meserve et al., 2016). Differences in ephemeral plant cover and composition among microhabitats (e.g., under shrub canopy vs. open microhabitat between shrubs) and between small mammal exclusion treatments are available in Madrigal et al. (2016) in this issue, and Meserve et al. (2003), respectively. The percent cover of ephemeral and perennial plants was estimated by the line-intercept method (MuellerDombois and Ellenberg, 1974) along four permanent 75-m transects per plot, spaced $15 \mathrm{~m}$ apart from one another. For measuring ephemeral plant cover, we randomly selected 10 1.5-m segments on each transect, and recorded the presence and absence of ephemeral plants at 30 points at 5 -cm intervals (i.e., 300 points per transect-line, 1200 points per plot). The same segments were sampled each year. For perennial plant cover, each $75-\mathrm{m}$ transect was subdivided into 150 points at 0.5 -m intervals (i.e., 600 points per plot). Percent cover was determined as $100 \mathrm{x}$ number of individual plants per point/total number of sampling points (Mueller-Dombois and Ellenberg, 1974). Individual plants were identified to the 
species level. As more than one individual may be intercepted per sampling point, cover values could exceed $100 \%$.

\subsection{Soil sampling and soil microbial analyses}

In 1997 we randomly selected three Adesmia shrubs of similar size (2-3 $\mathrm{m}^{2}$ in canopy cover area) in each plot (3 shrubs per plot in 4 plots per treatment [with vs. without the presence of small mammals]; therefore, 12 replicates per treatment level) and we collected paired soil samples under shrub canopies and in adjacent areas of bare ground at least $1 \mathrm{~m}$ away from the canopy edge (hereafter referred to as open spaces or open microhabitat). Soil samples were subsequently collected at the beginning of October from 1997 to 2006. This corresponds to mid-spring and occurs after winter rainfalls; as such it generally corresponds to the onset of senescence of the ephemeral plant community (depending on the pattern of annual rainfalls, plant cover peaks between August and October). Approximately $0.5 \mathrm{~kg}$ of soil was collected in each microsite from the top $20 \mathrm{~cm}$ of soil profile, where microbes and mycorrhizae fungi are most abundant; Aguilera et al. (1999) presented a similar analysis as here but spanned one year of measurements, and only included control plots. Most of the roots of ephemeral species and fine roots of the shrub species in this area occur within this $20 \mathrm{~cm}$ soil depth (Morales et al., 2015). Each soil sample was ca. $700 \mathrm{cc}$ in volume, corresponding to a hole $6-7 \mathrm{~cm}$ wide, $20 \mathrm{~cm}$ deep (e.g., $1.2 \times 10^{-3}$ to $5.4 \times 10^{-4}$ percent of the shrub canopy cover that is, on average, $2-3 \mathrm{~m}^{2}$ ). Each hole was refilled with soil from an adjacent Adesmia shrub and we payed close attention to not resample at the same spots where we had sampled in previous years. Each soil sample (from each shrub individual or open area) was thoroughly mixed and immediately separated into two subsamples which 
were stored in hermetically sealed plastic bags in a field cooler. These were transported to the laboratory and microbial analyses initiated on one subsample within $6 \mathrm{~h}$ of sample collection (see below). The other subsample was again divided in two parts: one was immediately weighed and used to measure soil gravimetric water content by subsequent drying in an oven, while the other part was sent to the Instituto de Investigaciones Agropecuarias (INIA) for soil physicochemical analyses (all analytical protocols from Porta et al., 1986): soils were first sieved through a $2 \mathrm{~mm}$ mesh and roots were removed; $\mathrm{pH}$ was determined in a 1:2.5 (w/v) suspension of soil in water and with a pH-meter (Hanna Instruments Model HI 2221, USA) and electrical conductivity was determined by the saturated-paste method and measured with a conductivimeter (Hanna Instruments Model HI 2300, USA). Total nitrogen (i.e., soil inorganic and organic N) concentration was estimated by Kjeldahl analysis in a semi-automatic analyser (Quimis Model Q328S21, UK ). Available phosphorus was extracted with a $0.5 \mathrm{M} \mathrm{NaHCO} 3$ solution at $\mathrm{pH} 8.5$ (Olsen method) and measured by colorimetry with a spectrophotometer (Spectronic D21, Milton Roy Limited, USA). Available potassium was extracted with $2 \mathrm{M}$ ammonium acetate $1 \mathrm{M}$ at pH 7.0 and measured an atomic spectrophotometer (Agilent Technologies AA 240, USA).

We estimated the percentage of root length colonized by arbuscular mycorrhizae (AM) fungi in fresh roots (1-2 $\mathrm{mm}$ dia.) isolated from each soil sample (for ephemerals in open areas) or directly from the root system of Adesmia. We followed sampling recommendations provided by Kormanik and McGraw (1982) and collected 10 to 20 segments of 1 to $2 \mathrm{~cm}$ long totaling $20 \mathrm{~cm}$ of root length per sample. These root samples were put in vials with $10 \mathrm{ml}$ of Formalin-Acetic-Alcohol fixing solution (FAA). Roots were then submerged in $10 \% \mathrm{KOH}$ at $90^{\circ} \mathrm{C}$, then washed with distilled water and stained with Trypan blue in lactoglycerol following a modification of the procedure by Phillips and 
Hayman (1970). A modified line-intercept method (McGonigle et al., 1990) was applied to determine the percentage of roots colonized by AM. For each sample, presence of hyphae, vesicles, and arbuscules was recorded and a minimum of 50 intersection points were scored in these root segments under a microscope (Nikon Eclipse E200, 400x magnification). Note that the percentage of ephemeral plant root length colonized by AM fungi (AM colonization intensity hereafter) was estimated for each sample irrespective of the ephemeral species involved, and thus is an estimate of mean community AM colonization intensity (Soudzilovskaia et al., 2015). Nonetheless, only 4 of the 54 ephemeral species present in this site had a mean ground cover greater than 5\% and were present in all the years measured (see Appendix 1, Table S1, Kelt et al., 2013); 8 other species had mean ground cover greater than $1 \%$, and not all were present in all years. All other species were much less abundant. Thus, the ephemeral roots sampled for AM analyses likely belonged to these four species across years, although we cannot be sure of this.

In each soil sample we also estimated the abundance of: 1) viable yeast and both saprophytic and mycorrhizae fungi, and 2) abundance of viable aerobic-mesophilicheterotrophic bacteria using the dilution plate count method (Parkinson et al., 1971). We air-dried $10 \mathrm{~g}$ of soil from each soil sample for $1 \mathrm{~h}$ and transferred these to dilution bottles containing $90 \mathrm{ml}$ of sterile deionized water. The soil solution was allowed to settle in the bottles for $15 \mathrm{~min}$ and was then shaken at $2800 \mathrm{rpm}$ for $15 \mathrm{~min}$ on a magnetic stirrer. Immediately following dispersion, we made five series of 10 -fold dilutions of the suspensions by pipetting $1 \mathrm{ml}$ aliquots into tubes containing $9 \mathrm{ml}$ of sterile deionized water. Thus, final dilutions were $10^{-6}$ fold from original concentrations. From this point, protocols to estimate bacteria and fungi differed. To tally viable bacteria, $1 \mathrm{ml}$ aliquot of each of the final three dilutions $\left(10^{-4}, 10^{-5}, 10^{-6}\right.$ of original dilution) were transferred to $9 \mathrm{~cm}$ diameter 
Petri dishes with $20 \mathrm{ml}$ of molten medium R2A agar (DIFCO Laboratories, Detroit, USA) and kept at $45^{\circ} \mathrm{C}$. This R2A agar was supplemented with $1 \%$ sterilized soil water extract obtained from a saturated soil paste extract of $10 \mathrm{~g}$ of soil. This addition of sterilized soil inoculum favors bacterial colony growth compared to R2A agar alone (Parkinson et al., 1971). The R2A agar was supplemented with $100 \mathrm{ug} / \mathrm{g}$ cycloheximide to avoid fungal growth. Petri dishes were incubated in a universal U-Memmert incubator at $25^{\circ} \mathrm{C}$ for 7 days, after which bacterial colonies were tailed. We followed a similar procedure to grow yeast and fungi, but for these the growing medium used was Potato Dextrose Agar (DIFCO Laboratories, Detroit, USA) supplemented with $1 \%$ sterilized soil water extract and 100 $\mathrm{ug} / \mathrm{g}$ tetracycline to avoid bacterial growth. As with bacteria, these Petri dishes were incubated at $25^{\circ} \mathrm{C}$ for 7 days and then yeast or saprophytic filamentous colonies were counted. The number of fungi and bacterial colonies that grew in each Petri dish ranged from 30-300 colonies. Each dish contained an etched grid of $1 \mathrm{~cm}^{2}$ squares, and we tallied the number of bacterial or fungal colonies under a stereoscopic microscope (Carton, 20x magnification). Abundance (colony forming units; $\mathrm{CFU} \mathrm{g}{ }^{-1}$ soil) was calculated as the number of colonies multiplied by the dilution factor applied on each dish.

\subsection{Statistical analysis}

We compared soil physicochemical characteristics, AM colonization intensity, and soil microbial (bacteria or fungi) abundance across the following fixed-factors: small mammal treatment (control vs. exclusion of small mammals), microhabitat (under shrub canopies vs. open areas), and time (10 years; 1997-2006). As our model was incomplete (e.g., we excluded degus from 1997 to 2000, but we excluded all small mammals from 2001 
onwards), we re-parametrized the model using two fixed factors, microhabitat and another single factor with 20 “small mammal_year” levels (i.e., 10 years x 2 small mammal treatment levels per year), and the interaction among these fixed factors. We thus have a design with 48 microsites per year (2 small mammal treatments per year, 4 plots each, 3 Adesmia shrubs per plot, 2 microhabitats at each shrub) and 10 years of monitoring (480 samples overall). For each dependent variable we performed an analysis of variance using general linear models. Sample measurements were repeated across years on the same shrubs and open spaces within the same plots, so we accounted for temporal correlation (dependence) among measurements using a first-order autocorrelation structure (corAR1; Gałecki and Burzykowski, 2013) on shrubs and open areas within plots and across years. We included soil physicochemical characteristics as covariates in the analyses of AM colonization intensity and soil microbial abundance. Several variables were $\ln$-transformed to meet assumptions of normality: soil fungi and bacterial abundance; soil organic matter; $\mathrm{N}, \mathrm{P}$, and $\mathrm{K}$ concentration; and soil conductivity. Whenever necessary, heterogeneous variances among treatments were modeled assigning different variances for each treatment (Gałecki and Burzykowski, 2013). Significance was established at $\mathrm{p}<0.05$ but we consider $\mathrm{p}<0.10$ to reflect "strong trends" that may have ecological importance. Post-hoc comparisons were performed using the Di Rienzo, Guzmán, and Casanoves test (universally referred to as the DGC test; Di Rienzo et al., 2002). We also performed multiple regression analyses to evaluate the relation of soil microbial abundance and AM root colonization with precipitation, soil physicochemical characteristics, and ephemeral or shrub cover. We first tested for (and confirmed the lack of) multicollinearity among predictor variables (the variance inflation factor for any predictor was $<5$ ). Analyses were conducted in R (R Development Core Team, 2013) using the interface implemented in 
InfoStat statistical software (v. 2013; http://www.infostat.com.ar). Data are given as means \pm 1 SE throughout ( $\mathrm{n}=3$ shrubs/open areas per plot, with 4 plots per biotic exclusion treatment).

\section{Results}

\subsection{Soil physiochemical characteristics}

Soil gravimetric water content (SWC) differed among years and was significantly correlated with annual rainfall $\left(r^{2}=0.62, P<0.001\right)$. SWC differed between microhabitats in some years (2001-2004) when SWC beneath shrubs was almost twice as high as in open spaces colonized by ephemeral plants (Fig. 1a, Table 1). Not surprisingly, SWC was highest in those years with high annual rainfall (e.g., >200 mm such as the ENSO year 1997, the period 2000-2002, see also SWC beneath shrubs in 2004) and, overall, lowest in years with annual rainfall below $100 \mathrm{~mm}$. Although SWC differed across small mammal_time levels (Table 1) they reflected differences across years more than across small mammal treatment levels (post-hoc data in Appendix S2, Table S3 see trends in Fig. 1a).

Soil $\mathrm{pH}$ and electrical conductivity (EC) generally were higher under shrubs than in open areas (Fig.1b, c; Table 1), and the latter exhibited a significant small mammal_time x microhabitat treatment interaction without a clear pattern in the differences among factors and across years. Patterns of soil $\mathrm{pH}$ were clearer than EC. Soil $\mathrm{pH}$ decreased during a very dry (1998) year and between 2001-2003 (two wet years followed by one dry year), particularly in open areas (post-hoc tests in Appendix S2, Table S3). In contrast, EC generally was greater under shrub canopies but exhibited some temporal fluctuations that 
appeared inconsistent across microhabitat and SM treatments. Soil nutrient concentration and SOM differed primarily among microhabitats (Fig. 1d-g) although this evidently was dependent on other treatments as there was a significant small mammal_time $\mathrm{x}$ microhabitat treatment interaction (Table 1). Overall, there were greater amounts of nutrients and soil organic matter (SOM) beneath shrubs than in open areas (Fig. 1; Table 1) and overall there were only modest and inconsistent differences in soil nutrient concentration and SOM content among SM treatments except for K concentration that was higher beneath shrubs where small mammals were present than in plots from which they were excluded (significant in 1997, 1999, 2002, 2004-06). However, the overall tendency for SOM content and nutrient concentration was for similar values among SM treatments (post-hoc tests in Appendix S2, Table S3; trends in Fig. 1). Nonetheless, there was no relation (or only a very weak one) between soil physicochemical characteristics and rainfall or SWC (Appendix 3, Table S4). For example, total N concentration was lowest in the prolonged rainy event of 2000-2002, and highest in the very dry La Niña event of 1998 and 1999, but it was also highest in two other rainy ENSO years (1997 and 2006) (Fig. 1).

\subsection{AM colonization intensity}

AM colonization of roots showed clear differences among small mammal_time levels and microhabitats (Fig. 2, Table 2). The percentage of mycorrhizae was lowest (ca. 20-50 \%) in rainy years with high rainfall (above $200 \mathrm{~mm}$ ) and highest (ca. 60-75 \%) in the driest years (La Niña 1998-99 years and 2003). Both shrubs and ephemerals displayed higher AM colonization intensity of roots in plots where small mammals were present $(+\mathrm{SM})$ in the prolonged rainy event (2000-2001); ephemeral plants also exhibited similar differences in 1998-99 (Fig. 2). A priori contrasts to check if the pattern of AM colonization intensity 
before and after 2001 could be associated to the presence of several small mammal species during the period of 1997-2000 in the -SM treatment (i.e., if there were differences between trends in plots with only degu excluded [1996-2000] or all small mammals excluded [2001 onwards]) showed no differences across -SM levels $\left(\mathrm{F}_{1,345}=0.36, \mathrm{p}=0.50\right)$.

AM colonization intensity was greater under shrub canopies (e.g., on roots of Adesmia shrubs) than in open areas (e.g., ephemeral plants), but only in some years (1997, 2005, 2006, Table 2 and post-hoc tests presented in Fig. 2). Multiple regression showed that annual rainfall, soil $\mathrm{pH}$, and $\mathrm{P}$ concentration were the principal factors affecting $\mathrm{AM}$ colonization intensity (Table 3 ), although soil $\mathrm{N}$ concentration and shrub cover tended to influence this as well. AM colonization of roots was positively associated with higher $\mathrm{pH}$ and nutrient concentration, but negatively so with rainfall, and tended towards negative association with shrub cover $(\mathrm{P}<0.1$, Table 3$)$.

\subsection{Soil microbial abundance}

Patterns for soil microbial abundance (fungi and bacteria) generally were opposite to that documented for AM colonization intensity. Abundance of fungi in soils showed clear differences among small mammal_time treatments, and particularly among microhabitats, although the interaction among both factors suggests particular trends (Fig. 3, Table 2). Soil fungi were most abundant (ca. 12-15.0 $\mathrm{CFU} \mathrm{g}^{-1}$ soil, $\ln$ scale) in years with highest rainfall (above $200 \mathrm{~mm}$ ), particularly in open areas, and they were least abundant (ca. 7.0 CFU g-1 soil, ln scale) in the driest year (La Niña 1998) although with similar low values in open areas in other dry years $(1999,2003-2006$, open sites in control plots with small mammal access). Overall, soil fungi were most abundant in plots where small mammals were excluded (-SM, irrespective of the exclusion only of degus [1996-2000] or all small 
mammals [2001 onwards]) and beneath shrubs (but see post-hoc tests; Fig. 3, Table 2). A priori contrasts showed no differences across $-\mathrm{SM}$ levels $\left(\mathrm{F}_{1,428}=1.79, \mathrm{p}=0.18\right)$.

Abundance of soil bacteria showed a more complex pattern than soil fungi (Table 2), although overall trends generally were similar across years (Fig. 4 vs 3). As with fungi, bacterial counts varied greatly across years and microhabitats; bacterial counts were highest in wet years (> $200 \mathrm{~mm}$ ) and lowest in the dry La Niña 1998 year (Fig. 4), and bacterial abundance was higher under shrubs than in open sites. Unlike fungi, there seemed to be no overall effect of small mammal treatments (see post-hoc tests in Fig.4) although results showed the influence of small mammal treatments in the context of other factors (significant microhabitat x small mammal_time interaction). Thus, within each microhabitat, soil bacterial abundance was similar among SM treatments in most years; however, bacterial abundance beneath the shrubs was higher in control plots than in small mammal exclusions in three years (1997, 1998 and 2001), and the opposite occurred in open sites in two years (1999 and 2006; Fig. 4). A priori contrasts showed differences across -SM levels $\left(\mathrm{F}_{1,428}=20.66, \mathrm{p}<0.001\right)$; that is, there were differences in bacteria counts when only degu was excluded [1996-2000] or all small mammals were excluded [2001 onwards]. However, Fig. 4 shows that differences in soil bacteria abundance between + SM treatment (free passage of all small mammals) and exclusion of degu or all small mammals were only significant for some particular years (1997-98 and 2001 beneath shrubs; 1999 and 2006 in open areas) both before and after the exclusion treatment changed. Thus, changes in soil bacteria abundance were probably more influenced by differences in rainfall and microhabitat conditions across years than by changes in the small mammal exclusion treatment. 
Multiple regression showed that annual rainfall, soil water content (SWC), soil $\mathrm{pH}$, soil electrical conductivity, and soil total $\mathrm{N}$ concentration were most strongly associated with abundance of soil fungi and bacteria (Table 3; SOM also affected soil bacteria abundance); of these, only total $\mathrm{N}$ showed a negative trend. Annual rainfall, by large, had the greatest influence on the models, followed by soil $\mathrm{pH}$ and EC. Shrub and ephemeral plant covers did not seem to have a significant linear effect on the abundance of soil microorganisms.

\section{Discussion}

Abundance of soil microorganisms in semiarid Chile was strongly influenced by annual precipitation; rainfall negatively affected AM colonization intensity but positively affected the abundance of free-living soil microorganisms. This may be an expected result for this semiarid ecosystem, and it likely is not surprising that the abundance of soil microorganisms varied in relation to the spatial and temporal heterogeneity of soil physicochemical properties, which in turn were influenced by the distribution of vegetation. Somewhat unexpected, however, is the overriding influence that small mammals had in modulating responses of soil microbiota to these more immediate influences, and we believe this underscores the importance of long-term studies incorporating diverse facets of ecosystem structure and function.

\subsection{Soil physiochemical characteristics across microhabitats and years}

Similar to many other arid and semiarid environments, our system was characterized by large temporal variation in annual rainfall and, to a lesser extent, in soil physiochemical 
characteristics (Ward, 2009; Whitford, 2002). Nutrient concentrations and SOM content generally were greater beneath shrubs than in open sites. Thus, as in many drylands, accumulation of litter and soil organic matter, and the milder microclimatic conditions under the shade of shrubs, can lead to hubs of soil fertility beneath their canopies and the development of "resource islands" (Pugnaire et al., 2011; Reynolds et al., 1999; Schlesinger et al., 1996).

As expected, rainfall and soil water content were correlated; nonetheless, temporal dynamics of soil nutrient concentration was not related with soil water content. Soils in the Fray Jorge LTSER are loamy with 85\% sand (Aguilera et al., 1999) and thus, soil water holding capacity is low and infiltration to relatively deep soil profiles is high. However, because nutrients accumulate in the first centimeters of soil (Reynolds et al., 1999; Whitford, 2002), the effect of soil water content on nutrient dynamics given this soil texture may be relatively small compared to more finely textured soils (Ward, 2009). We also recognize that measuring soil water content only once at the end of the rainy season captures shorter-term variation within the year, likely reducing our ability to detect an important role of soil water. Nonetheless, in semiarid environments, abiotically driven decomposition of litter and SOM can decouple biogeochemical cycles from water availability (Austin, 2011). Soil N concentration was lower during prolonged periods of high rainfall (e.g., 2000-2002) compared to other years. Higher N immobilization into microbial or plant biomass during consecutive high rainfall years might lead to depletion of soil N (Gutiérrez and Whitford, 1987). In fact, in our study, both abundance of soil microbes and cover of ephemeral plants were positively associated with rainfall (Appendix 3, Table S4). However, leaching of soluble nutrients (e.g., nitrate- and salts to deeper soil profiles) may have played a role as well, which may explain the neutral to relatively acidic 
soil $\mathrm{pH}$ and the lower soil conductivity during rainy years. Moreover, soil excavation and mixing may have stimulated $\mathrm{N}$ mineralization of soil samples, particularly in dry years (Raison et al., 1987, but note that we measured total N content). Overall, in our study, comparisons of soil $\mathrm{N}$ across years with contrasting rainfall should be made with caution.

\subsection{AM colonization intensity}

Arbuscular mycorrhizae enable plants to extract nutrients even from solid inorganic particles in very poor soils, and are important for sustaining plant growth in harsh environments (Allen, 2007; Barea et al., 2011). Under dry conditions they may help alleviate water deficit for host plants by increasing the rhizosphere absorbing surface via fungi mycelia (Allen, 2007). Overall, plant-AM interactions are considered to be critical drivers of plant community responses to variation in rainfall (Zobel and Öpik, 2014), although long-term studies with field plant communities subjected to different drought conditions are still needed (Mohan et al., 2014).

Our long-term study showed that AM colonization of roots of both shrub and ephemeral plants was lowest during rainy years, particularly in years with annual rainfall greater than $200 \mathrm{~mm}$ (ca. 1.6 times the mean annual rainfall in this area), whereas it was highest during dry years. Moreover, rainfall was the main factor affecting AM abundance in our system. Cumulatively, these observations suggest that, as in other semiarid ecosystems, mycorrhizae in our system play an important role in improving the resilience of plant communities against environment stresses, including nutrient deficiency and drought (Barea et al., 2011). However, during wet years when more water and nutrients are available for plants (both ephemerals and perennials), the costs for the host plant (e.g., in terms of $\mathrm{C}$ exchange to the fungus) may inhibit AM maintenance to some extent. This is in 
agreement with other studies that showed that AM abundance is inversely correlated with soil moisture (Harnett and Wilson, 1999) and with a recent meta-analysis (Kivlin et al., 2013) that showed that AM significantly increased plant growth in drought conditions, alleviating the negative effects of water deficit on plant growth. To our knowledge this may be the first long-term field study that documents so clearly the impact of interannual variation in rainfall on a highly dynamic AM colonization intensity in desert plant communities.

Results also showed that soil characteristics were important in predicting AM abundance, particularly $\mathrm{pH}$ and $\mathrm{P}$ concentration that were positively associated with $\mathrm{AM}$ colonization intensity; in contrast, total $\mathrm{N}$ concentration showed a marginally negative effect on AM colonization intensity. Soil $\mathrm{pH}$ values ranged over a unit (e.g., between $\mathrm{pH}$ 6.2 and 7.3) and, while this is a broad range, other studies showing differential responses of AM colonization to soil $\mathrm{pH}$ usually report even wider $\mathrm{pH}$ ranges (e.g., between $\mathrm{pH} 4$ [acid soils] and pH 8 [alkaline soils]; Rousk et al., 2009). In our P-limited system, it is likely that slight changes in pH may influence $\mathrm{P}$ availability, which increases in alkaline soils; in contrast, in mildly acidic soils ( $\mathrm{pH}<6.0)$, $\mathrm{P}$ may precipitate with $\mathrm{Al}$ or $\mathrm{Fe}$, becoming unavailable for plants (Brady and Weil, 2008). Nonetheless, most studies showing changes in $\mathrm{AM}$ colonization as a function of $\mathrm{P}$ concentration report negative or no relationship between AM abundance and P concentration (Smith et al., 2011; Soudzilovskaia et al., 2015 and cites therein).

Finally, few studies have analyzed whether plant-AM mutualisms may be influenced by the presence of organisms from higher trophic levels. At our site, the presence of small mammals (mostly herbivores foraging on ephemeral plants) positively influenced AM colonization of roots, particularly of the ephemeral plant community, yet 
had negligible effects on soil physicochemical properties. There may be two explanations for this positive AM-small mammal interaction; either it is a response of the plant community to herbivory or disturbance (Barea et al., 2011), or small mammals may have served as successful AM spore dispersers, either externally as spores attach to their fur while foraging (mainly ephemerals) or digging burrows (ectozoochorus dispersal), or internally (endozoochorous dispersal); it is acknowledged that mycophagy by mammals, particularly ectomycorrhizal fungi, can be a key dispersal mechanism (e.g., Nuñez et al. 2013, Wood et al., 2015). Godfrey (1957) showed successful endozoochorous dispersal by rodents of spores of the AM fungi Endogone sp., and Warner et al. (1987) reported dispersal of AM fungi by five species of mammals (including two rodents) from an arid ecosystem in southwestern Wyoming, USA, although the mechanisms were unclear. Frank et al. (2009) reported that dispersal of spores of AM fungi attached to the fur of some small mammal species may be a key factor in the successful establishment of Quercus garryana tree seedlings in North America. Finally, Wood et al. (2015) showed that exotic herbivores from North America and Australia facilitate the dispersion of non-native ectomycorrhizal fungi (via endozoochorous dispersal) that facilitate the establishment of North American pines in New Zealand; in contrast, native trees were not colonized by these ectomycorrhizal fungi. Our results appear to concur with these studies; small mammals in our system evidently disperse AM spores, either by epizoochory, likely acquiring these while foraging or digging burrows, or by endozoochory as they forage on roots and the attached soil.

\subsection{Soil fungi and bacteria abundance}

The community of soil bacteria and, to a lesser extent, the free-living soil fungal community analyzed in our study are key drivers of litter and soil organic matter 
decomposition, and soil bacteria drive nutrient mineralization (Aguilera et al., 1999), thereby playing an important role releasing nutrients that can be taken up by plants. Control of carbon and nutrient cycling in arid ecosystems has been attributed mainly to water availability (and its pulsed nature) which ultimately controls plant productivity and the soil biota responsible for litter and SOM decomposition (Austin et al., 2004; Noy-Meir, 1973; Whitford, 2002). However, photodegradation of aboveground litter and the spatial heterogeneity as a modulator of soil biotic responses to water availability may also have been important (Austin, 2011). Our results showed that soil fungi and bacteria were more abundant during wet years, particularly in very high-rainfall ones, and that soil water availability, SOM, and $\mathrm{pH}$ had a positive effect on the abundance of soil microorganisms. Similar patterns have been reported from many other semiarid ecosystems (Austin et al., 2004; Hu et al., 2014). In the Chihuahuan Desert, pulses of water due to simulated rainfall provoked a rapid response and increase in soil microbial activity (Parker et al., 1984); indeed, the temporal fluctuation of soil water was the only abiotic factor in this desert that significantly influenced the number of soil microorganisms (Herman et al., 1994).

Many studies have documented a positive relation between soil $\mathrm{N}$ concentration and soil microbial growth in arid ecosystems (e.g., Chinnadurai et al., 2014; Housman et al., 2007). In addition, the shrub cover that acts as a nutrient resource island here (Pugnaire et al, 2011; Reynolds et al., 1999; Schlesinger et al., 1996) likely hosts higher microbial abundance and activity than the relatively nutrient-poor open spaces between shrubs (Aguilera et al., 1999; Goberna et al., 2007; Hortal et al., 2013). In our study all microorganisms were more abundant in soils beneath shrubs (relative to open areas) and soil microbial abundance fluctuated more in open areas than under shrub-resource islands. However, we also found a clear negative relation between soil microbial abundance and 
soil $\mathrm{N}$ which declined in wet years (but see exceptions in Fig. 1, as 1997 for N). This negative relationship may reflect the long-term and community level soil $\mathrm{N}$ biogeochemical dynamics typical for water-pulsed ecosystems. As Austin et al. (2004) noted, the accumulation of inorganic $\mathrm{N}$ in semiarid ecosystems usually occurs during dry periods, adding to the accumulation of organic soil $\mathrm{N}$ in the form of dead ephemeral plant biomass, litter, and the dead microbial community that thrives during wet conditions. This relationship may result in temporally separate periods of maximum water and soil nutrient concentrations, both within and across years, with periods of high nutrient concentrations occurring when plants are either senescent or unable to respond to nutrient pulses (Austin et al., 2004; and references cited therein).

An unexpected and important result in our study was the effect of small mammals on the abundance of free-living soil microbes and the lack of a significant effect of shrub or ephemeral plant cover. In contrast to the trend observed with AM, there was a negative interaction between the abundance of small mammals and of soil fungi, a similar negative effect of small mammals on soil bacteria in open areas, but a positive interaction beneath Adesmia shrubs. This community of small mammals includes folivores, granivores, and omnivores that may preferentially feed in open areas, but they exhibit risk-sensitive foraging, avoiding open areas in general, and they usually burrow and defecate under the shrubs (Lagos et al., 1995; and references cited therein). Small mammals are known to affect the structure and physicochemical characteristics of soils in deserts (e.g., Whitford, 2002; Whitford and Steinberger, 2010, Kelt 2011), and although we did not clearly trace these soil changes, they may have positively influenced soil bacteria at our site. Nonetheless, further studies are needed to better understand the direct and indirect effects of small mammals on the soil biota in this ecosystem. 
In conclusion, the abundance of belowground microorganisms in a semiarid shrubland in north-central Chile was influenced primarily by variation in annual rainfall and both the spatial and temporal heterogeneity in soil resources; open areas with low cover of ephemeral plants were relatively poor in resources relative to resource islands beneath the canopy of Adesmia bedwellii. These dynamics were modulated by the presence of the small mammal community which influenced plant-AM associations as well as the abundance of soil fungi and soil bacteria. In dry years with low primary productivity and vegetative cover, plant-AM associations were more extensive for both ephemeral and perennial plant species, suggesting a mutualistic association during drought periods that may contribute to alleviate water deficits and environmental stress for the host plant. During wet years an increase in the abundance of free-living soil microorganisms was likely responsible for the decomposition of litter and soil organic matter, and for nutrient mineralization. This pulse of nutrients and soil water may sustain the high ephemeral plant cover observed in this semiarid community during El Niño wet years. The spatial and temporal heterogeneity of resources and activity of small mammals may have an overriding importance as modulators of belowground biotic responses in this semiarid ecosystem. These observations underscore the importance of long-term field research but also emphasize the need for further research on aboveground/belowground dynamics in arid regions. In the face of global climate change and desertification, better understanding of the factors governing nutrient cycling in arid lands should be a high priority for ecologists.

\section{Acknowledgements}

We thank D. Hiriart and J. Molina for their assistance in the field and in the lab performing microbial analyses. We are grateful to the Corporación Nacional Forestal (CONAF) from 
the IV Región for assistance at Bosque Fray Jorge National Park. This work was funded by grants from FONDECYT 1970576, 1000041, and 1030225 and the US National Science

Foundation (most recently, NSF-LTREB DEB 1456729 to DAK and PLM) and DIULS

2004 to LA. CA was granted with a postdoctoral fellowship from the Institute of Ecology

and Biodiversity with the financial support of contract ICM P05-002, a RyC contract

(RYC-2012-12277) and grant (CGL2014-59010-R) from the Spanish Government..

\section{References}

Aguiar, M.R., Sala, O.E., 1999. Patch structure, dynamics and implications for functioning of arid ecosystems. Trends in Ecology and Evolution 14, 273-277.

Aguilera, L.E., Gutierrez, J.R., Meserve, P.L., 1999. Variation in soil micro-organisms and nutrients underneath and outside the canopy of Adesmia bedwellii (Papilionaceae) shrubs in arid coastal Chile following drought and above average rainfall. Journal of Arid Environments 42, 61-70.

Allen, M.F., 2007. Mycorrhizal fungi: Highways for water and nutrients in arid soils. Vadose Zone Journal 6, 291-297.

Anderson, C.B., Likens, G.E., Rozzi, R., Gutiérrez, J.R., Armesto, J.J., Poole, A., 2008. Integrating science and society through long-term socio-ecological research. Environ Ethics 30, 295-312.

Armas, C., Gutiérrez, J.R., Kelt, D.A., Meserve, P.L., 2016. Editorial. Twenty-five years of research in the north-central Chilean semiarid zone: The Fray Jorge Long-Term SocioEcological Research (LTSER) site and Norte Chico. Journal of Arid Environments in this issue. Austin, A.T., 2011. Has water limited our imagination for arid land biogeochemistry? Trends in Ecology and Evolution 26, 229-235.

Austin, A.T., Yahdjian, L., Stark, J.M., Belnap, J., Porporato, A., Norton, U., Ravetta, D.A., Schaeffer, S.M., 2004. Water pulses and biogeochemical cycles in arid and semiarid ecosystems. Oecologia 141, 221-235.

Bardgett, R.D., Wardle, D.A., 2010, Aboveground-Belowground Linkages: Biotic Interactions, Ecosystem Processes, and Global Change., New York, Oxford University Press.

Barea, J.M., Palenzuela, J., Cornejo, P., Sánchez-Castro, I., Navarro-Fernández, C., López-García, A., Azcón, R., Ferrol, N., Azcón-Aguilar, C., 2011. Ecological and functional impact of mycorrhizas in semiarid ecosystems of Souteast Spain. Journal of Arid Environments 75, 1292 1301.

Bever, J.D., Dickie, I.A., Facelli, E., Facelli, J.M., Klironomos, J.N., Moora, M., Rillig, M.C., Stock, W.D., Tibbett, M., Zobel, M., 2010. Rooting theories of plant community ecology in microbial interactions. Trends in Ecology and Evolution 25, 468-478.

Brady, N.C., Weil, R.R., 2008, The nature and properties of soil, New Jersey, USA, Pearson Prentice Hall.

Callaway, R.M., 2007, Positive interactions and interdependence in plant communities, Dordrecht, Springer.

Chinnadurai, C., Gopalaswamy, G., Balachandar, D., 2014. Long term effects of nutrient management regimes on abundance of bacterial genes and soil biochemical processes for fertility sustainability in a semi-arid tropical Alfisol. Geoderma 232-234, 563-572. 
Di Rienzo, J.A., Guzmán, W., Casanoves, F., 2002. A multiple-comparisons method based on the distribution of the root node distance of a binary tree. Journal of Agricultural, Biological, and Environmental Statistics 7, 129-142.

Frank, J.L., Anglin, S., Carrington, E.M., Taylor, D.S., Viratos, B., Southworth, D., 2009. Rodent dispersal of fungal spores promotes seedling establishment away from mycorrhizal networks on Quercus garryana. Botany 87, 821-829.

Gałecki, A., Burzykowski, T., 2013, Linear Mixed-Effects Models Using R: A Step-by-Step Approach, Springer.

Goberna, M., Pascual, J.A., Garcia, C., Sanchez, J., 2007. Do plant clumps constitute microbial hotspots in semiarid Mediterranean patchy landscapes? Soil Biology \& Biochemistry 39, 10471054.

Godfrey, R.M., 1957. Studies on British species of Endogone. III. Germination of spores. Transactions of the British Mycological Society 40, 203-210.

Gutiérrez, J.R., Meserve, P.L., Kelt, D.A., Engilis, A., Jr., Previtali, M.A., Milstead, W.B., Jaksic, F.M., 2010. Long-term research in Bosque Fray Jorge National Park: Twenty years studying the role of biotic and abiotic factors in a Chilean semiarid scrubland. Revista Chilena De Historia Natural 83, 69-98.

Gutiérrez, J.R., Whitford, W.G., 1987. Responses of Chihuahuan Desert herbaceous annuals to rainfall augmentation. Journal of Arid Environments 12, 127-140.

Harnett, D.C., Wilson, G.W.T., 1999. Mycorrhizae influence plant community structure and diversity in tallgrass prairie. Ecology 80, 1197-1195.

Herman, R.P., Provencio, K., Torres, R., Seager, G.M., 1994. Seasonal and spatial population dynamics of the nitrogen-efficient guild in a Desert Bajada grassland. Applied and Environmental Microbiology 60, 1160-1165.

Holmgren, M., Lopez, B.C., Gutierrez, J.R., Squeo, F.A., 2006. Herbivory and plant growth rate determine the success of El Nino Southern Oscillation-driven tree establishment in semiarid South America. Global Change Biology 12, 2263-2271.

Hortal, S., Bastida, F., Armas, C., Lozano, Y.M., Moreno, J.L., Garcia, C., Pugnaire, F.I., 2013. Soil microbial community under a nurse-plant species changes in composition, biomass and activity as the nurse grows. Soil Biology \& Biochemistry 64, 139-146.

Housman, D.C., Yeager, C.M., Darby, B.J., Sanford Jr., R.L., Kuske, C.R., Neher, D.A., Belnap, J., 2007. Heterogeneity of soil nutrients and subsurface biota in a dryland ecosystem. Soil Biology and Biochemistry 39, 2138-2149.

Hu, Y., Xiang, D., Veresoglou, S.D., Chen, F., Chen, Y., Hao, Z., Zhang, X., Chen, B., 2014. Soil organic carbon and soil structure are driving microbial abundance and community composition across the arid and semi-arid grasslands in northern China. Soil Biology and Biochemistry 77, 51-56.

Jiménez, M.A., Jaksic, F.M., Armesto, J.J., Gaxiola, A., Meserve, P.L., Kelt, D.A., Gutiérrez, J.R., 2011. Extreme climatic events change the dynamics and invasibility of semi-arid annual plant communities. Ecology Letters 14, 1227-1235.

Kelt, D.A., 2011. Comparative ecology of desert small mammals: a selective review of the past 30 years. Journal of Mammalogy 92, 1158-1178.

Kelt, D.A., Meserve, P.L., Gutiérrez, J.R., Milstead, W.B., Previtali, M.A., 2013. Long-term monitoring of mammals in the face of biotic and abiotic influences at a semiarid site in northcentral Chile. Ecology 94, 977-977.

Kivlin, S.N., Emery, S.M., Rudgers, J.A., 2013. Fungal symbionts alter plant responses to global change. American Journal of Botany 100, 1445-1457.

Kormanik, P.P., McGraw, A.C., 1982. Quantification of vesicular-arbuscular mycorrhizae in plant roots, in: Schenk, N.C. (Ed.), Methods and principles of mycorrhizal research. American Phytopathological Society, St Paul, MN, USA, pp. 37-45. 
Lagos, V.O., Contreras, L.C., Meserve, P.L., Gutierrez, J.R., Jaksic, F.M., 1995. Effects of predation risk on space use by small mammals: A field experiment with a Neotropical rodent. Oikos 74, 259-264.

Lozano, Y.M., Hortal, S., Armas, C., Pugnaire, F.I., 2014. Interactions among soil, plants, and microorganisms drive secondary succession in a dry environment. Soil Biology \& Biochemistry 78, 298-306.

Madrigal-González, J., Kelt, D.A., Meserve, P.L., Squeo, F.A., Gutiérrez, J.R., 2016. Shrubephemeral plants interactions in semiarid north-central Chile: is the nurse plant syndrome manifested at the community level? Journal of Arid Environments in this issue.

McGonigle, T.P., Miller, M.H., Evans, D.G., Fairchild, G.L., Swan, J.A., 1990. A new method which gives an objective measure of colonization of roots by vesicular-arbuscular mycorrhizal fungi New Phytologist 155, 495-501.

Meserve, P.L., Kelt, D.A., Gutiérrez, J.R., Previtali, M.A., Milstead, W.B., 2016. Biotic interactions and community dynamics in the semiarid thorn scrub of Bosque Fray Jorge National Park, north-central Chile: a paradigm revisited. Journal of Arid Environments in this issue.

Meserve, P.L., Kelt, D.A., Milstead, W.B., Gutierrez, J.R., 2003. Thirteen years of shifting topdown and bottom-up control. Bioscience 53, 633-646.

Mohan, J.E., Cowden, C.C., Baas, P., Dawadi, A., Frankson, P.T., Helmick, K., Hughes, E., Khan, S., Lang, A., Machmuller, M., Taylor, M., Witt, C.A., 2014. Mycorrhizal fungi mediation of terrestrial ecosystem responses to global change: mini-review. Fungal Ecology 10, 3-19.

Montecinos, S., Gutiérrez, J.R., López-Cortés, F., López, D., 2016. Climatic characteristics of the semi-arid Coquimbo Region in Chile. Journal of Arid Environments in this issue.

Morales, J., Squeo, F.A., Tracol, Y., Armas, C., Gutiérrez, J.R., 2015. Resource economics and coordination among above- and below-ground functional traits of three dominant shrubs from the Chilean coastal desert Journal of Plant Ecology 8, 70-78.

Mueller-Dombois, D., Ellenberg, H., 1974, Aims and Methods of Vegetation Ecology, New York, Wiley.

Noy-Meir, I., 1973. Desert Ecosystems: Environment and Producers. Annual Review of Ecology and Systematics 4, 25-51.

Nuñez, M.A., Hayward, J., Horton, T.R., Amico, G.C., Dimarco, R.D., Barrios-Garcia, M.N., Simberloff, D., 2013. Exotic mammals disperse exotic fungi that promote invasion by exotic trees. PLoS One 8, e66832.

Parker, L.W., Freckman, D.W., Steinberger, Y., Driggers, L., Whitford, W.G., 1984. Effects of simulated rainfall and litter quantities on desert soil biota: soil respiration, microflora and protozoa. Pedobiologia 27, 185-195.

Parkinson, D., Gray, T.R.G., Williams, S.T., 1971, Methods for studying the ecology of soil microorganisms: IBP Handbook, v. 19, Oxford, UK, Blackwell Scientific Publications.

Phillips, J.M., Hayman, D.S., 1970. Improved procedures for clearing roots and staining parasitic and vesiculo-arbuscular mycorrhizae fungi for rapid assessment of infection. Transactions of the British Mycological Society 55, 158-161.

Porta, J., López-Acevedo, M., Rodríguez, R., 1986, Técnicas y Experimentos en Edafología, Barcelona, Spain, Colegio Oficial de Ingenieros Agronomos de Cataluña.

Pugnaire, F.I., Armas, C., Maestre, F.T., 2011. Positive plant interactions in the Iberian Southeast: Mechanisms, environmental gradients, and ecosystem function. Journal of Arid Environments $75,1310-1320$.

Raison, R.J., Connell, M.J., Khanna, P.K., 1987. Methodology for studying fluxes of soil mineral$\mathrm{N}$ in situ. Soil Biology and Biochemistry 19, 521-530.

Reynolds, J.F., Virginia, R.A., Kemp, P.R.d.S., A. G., Tremmel, D.C., 1999. Impact of drought on desert shrubs: effects of seasonality and degree of resource island development. Ecological Monographs 69, 69-106. 
Rousk, J., Brookes, P.C., Bååth, E., 2009. Contrasting soil pH effects on fungal and bacterial growth suggest functional redundancy in carbon mineralization. Applied and Environmental Microbiology 75, 1589-1596.

Schlesinger, W.H., Raikes, J.A., Hartley, A.E., Cross, A.F., 1996. On the spatial pattern of soil nutrients in desert ecosystems. Ecology 77, 364-374.

Smith, S.E., Jakobsen, I., Gronlund, M., 2011. Roles of arbuscular mycorrhizas in plant phosphorus nutrition: interaction between pathways of phosphorus uptake in arbuscular mycorrhizal roots have important implications for understanding and manipulating plant phosphorus acquisition. Plant Physiology 156, 1050-1057.

Soudzilovskaia, N.A., Douma, J.C., Akhmetzhanova, A.A., van Bodegom, P.M., Cornwell, W.K., Moens, E.J., Treseder, K.K., Tibbett, M., Wang, Y.-P., Cornelissen, J.H.C., 2015. Global patterns of plant root colonization intensity by mycorrhizal fungi explained by climate and soil chemistry. Global Ecology and Biogeography 24, 371-382.

Ward, D., 2009, The Biology of Deserts, New York, USA, Oxford University Press.

Wardle, D.A., Bardgett, R.D., Klironomos, J.N., Setala, H., van der Putten, W.H., Wall, D.H., 2004. Ecological linkages between aboveground and belowground biota. Science 304, 1629 1633.

Warner, N.J., Allen, M.F., MacMahon, J.A., 1987. Dispersal agents of vesicular-arbuscular mycorrhizal fungi in a disturbed arid ecosystem. Mycologia 79, 721-730.

Whitford, W.G., 2002, Ecology of Desert Systems, Academic Press.

Whitford, W.G., Steinberger, Y., 2010. Pack rats (Neotoma spp.): Keystone ecological engineers? Journal of Arid Environments 74, 1450-1455.

Wood, J.R., Dickie, I.A., Moeller, H.V., Peltzer, D.A., Bonner, K.I., Rattray, G., Wilmshurst, J.M., 2015. Novel interactions between non-native mammals and fungi facilitate establishment of invasive pines. Journal of Ecology 103, 121-129.

Zobel, M., Öpik, M., 2014. Plant and arbuscular mycorrhizal fungal (AMF) communities - which drives which? Journal of Vegetation Science 25, 1133-1140. 


\section{Figure legends}

Figure 1.- Soil Water Content (SWC) (a), pH (b), Electrical Conductivity (EC) (c), and concentration of total Nitrogen (d), available Phosphorus (e), Potassium (f), and Organic Matter (g) content in soils from 1997 through 2006 in plots where small mammals were present (+SM) or excluded (-SM; either only degus [1997-2000] or all small mammals [2001-2006] were excluded) and in two microhabitats (beneath the canopy of Adesmia bedwellii shrubs or in open spaces). Data are raw mean values $( \pm \mathrm{SE})$ from three shrubs/open spaces in each of four plots per SM biotic treatment. Annual rainfall is included as bars in the SWC panel (a); mean annual rainfall is ca. $127 \mathrm{~mm}$ and crosshatched bars signify much higher rain than normal rainfall years, i.e. $>200 \mathrm{~mm}$, while clear bars signify lower than $<200 \mathrm{~mm}$. Statistical results are shown in Table 1 and Appendix 2.

Figure 2.- AM colonization intensity (percentage of root length colonized by AM fungi; mean \pm S.E.) in roots of Adesmia bedwellii shrubs (upper panel) and ephemeral plants roots from open spaces (lower panel) from 1997 through 2006 in plots where small mammals were present (+SM) or excluded (-SM; either only degus [1997-2000] or all small mammals [2001-2006] were excluded). Annual rainfall is included in the lower panel as in Fig. 1a. Results from the two microhabitats (M) are presented in separate panels for clarity, but all data were analyzed together; symbols with different letters (irrespective of the panel) are different after post-hoc DGC test. Statistical results are shown in Table 2.

Figure 3.- Abundance of soil fungi (mean \pm S.E.) under Adesmia bedwellii shrubs (upper panel) and open spaces (lower panel) from 1997 through 2006 in plots where small mammals were present (+SM) or excluded (-SM; either only degus [1997-2000] or all 
small mammals [2001-2006] were excluded). Error bars are presented but are visible only where they are greater than symbol size. See legend of Fig. 2 for further details.

Figure 4.- Abundance of soil bacteria under Adesmia bedwellii shrubs (upper panel) and open spaces (lower panel) from 1997 through 2006 in plots where small mammals were present (+SM) or excluded (-SM; either only degus [1997-2000] or all small mammals [2001-2006] were excluded). Error bars are presented but are visible only where they are greater than symbol size. See legend of Fig. 2 for further details. 
Table 1.- Results (F-values) from general linear models on: Soil Water Content (SWC), soil Electrical Conductivity (EC), pH, Organic Matter (SOM) content, and concentration of soil total Nitrogen (N), available Phosphorus (P) and Potassium (K). Small mammal_Time (control or with either degus [1997-2000] or all small mammals [2001-2006] excluded per year), Microhabitat (M; under shrub canopy vs. open spaces) and the interaction were considered fixed factors. All results were significant except for SOM differences across SM_Y levels; $*, * *, * * *$ for $\mathrm{p}<0.05,0.01,0.001$, respectively.

\begin{tabular}{|c|c|c|c|c|c|c|c|c|}
\hline & \\
\hline & df & SWC & $\mathrm{EC}$ & $\mathrm{pH}$ & SOM & $\mathrm{N}$ & $\mathrm{P}$ & $\mathrm{K}$ \\
\hline Small Mammal_Time (SM_Y) & 19 & $36.96^{* * *}$ & $6.01 * * *$ & $11.07 * * *$ & 1.15 & $6.56 * * *$ & $4.82 * * *$ & $4.00 * * *$ \\
\hline Microhabitat (M) & 1 & $65.88 * * *$ & $281.93 * * *$ & $148.22 * * *$ & $189.24 * * *$ & $49.79 * * *$ & $37.19 * * *$ & $50.41 * * *$ \\
\hline SM_Y x M & 19 & $3.48 * * *$ & $2.47 * * *$ & $1.66^{*}$ & $2.23 * *$ & $1.75^{*}$ & $2.01 * *$ & $1.87 *$ \\
\hline
\end{tabular}


Table 2.- Results (F-values) from general linear models on AM colonization intensity and abundance of fungi and bacteria in soils. The following soil variables were included as covariates: Soil Water Content (SWC), Electrical Conductivity (EC), pH, Organic Matter (SOM) content, and concentration of total Nitrogen $(\mathrm{N})$, available Phosphorus $(\mathrm{P})$ and Potassium (K). Small mammal_Time (SM; control or with either degus [1997-2000] or all small mammals [2001-2006] excluded per year), Microhabitat (under the shrub or in open spaces) and the interaction were considered fixed factors. All significant results are highlighted in bold; *,**, *** for $\mathrm{p}<0.05,0.01,0.001$, respectively.

\begin{tabular}{l|c|ccc}
\cline { 2 - 5 } & \multicolumn{1}{c}{ df } & AM & Fungi & Bacteria \\
\hline Small Mammal_Time (SM_Y) & 19 & $\mathbf{2 7 . 1 0 * * *}$ & $\mathbf{2 6 . 7 2 * * * *}$ & $\mathbf{4 6 . 6 5 * * *}$ \\
Microhabitat (M) & 1 & $\mathbf{9 . 4 1 * *}$ & $\mathbf{2 6 4 . 3 0 * * * *}$ & $\mathbf{1 4 4 3 . 8 0 * * *}$ \\
\hline SWC & 1 & 0.07 & 0.68 & 0.05 \\
pH & 1 & 1.68 & $<0.01$ & 0.52 \\
EC & 1 & 0.12 & 0.35 & 0.07 \\
SOM & 1 & 0.05 & 0.01 & 0.97 \\
N & 1 & 1.07 & 0.15 & 2.65 \\
P & 1 & 0.01 & 0.82 & 1.10 \\
K & 1 & 0.71 & 0.07 & 0.03 \\
\hline SM_Y X M & 19 & 1.42 & $\mathbf{9 . 5 5 * * *}$ & $\mathbf{2 1 . 0 9 * * *}$ \\
\hline
\end{tabular}


Table 3.- Multiple regression models of AM colonization intensity, and abundance of fungi and bacteria in soils. The following variables were included as regressors: Annual rainfall (Rain), Cover of ephemerals (Annuals_cov), Cover of shrubs (Shrub_cov), Soil Water Content (SWC), Electrical Conductivity (EC), pH, Organic Matter (SOM) content, and concentration of total Nitrogen $(\mathrm{N})$, available Phosphorus (P) and Potassium (K). Presented are degrees of freedom (df), test statistic $(\mathrm{F})$, and the slope of the regression for significant results. Significant values are highlighted in bold; $*$, **, *** for $\mathrm{p}<0.05,0.01,0.001$, respectively, ${ }^{\mathrm{TR}}$ for $\mathrm{p}<0.1$.

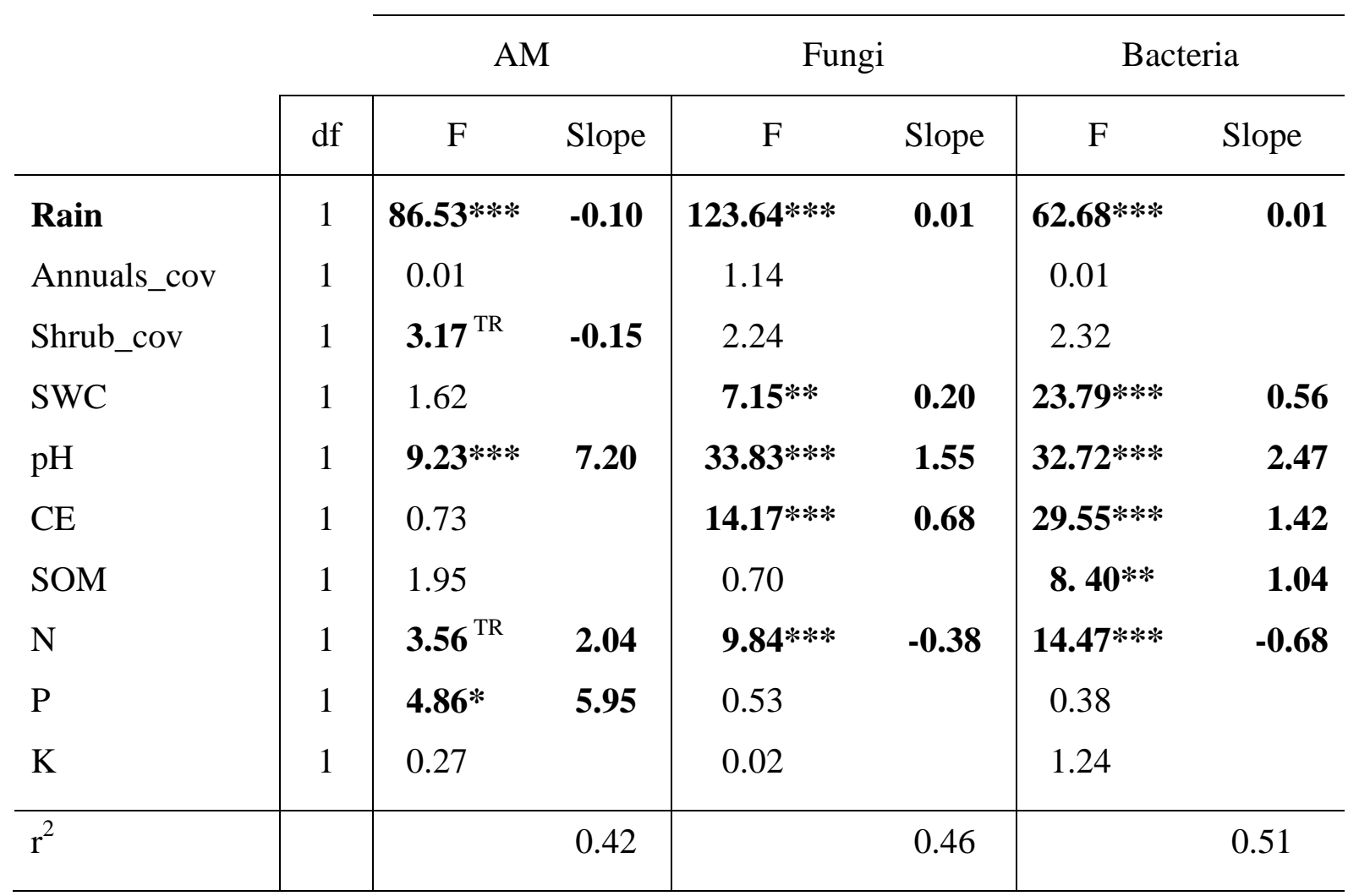


Figure 1
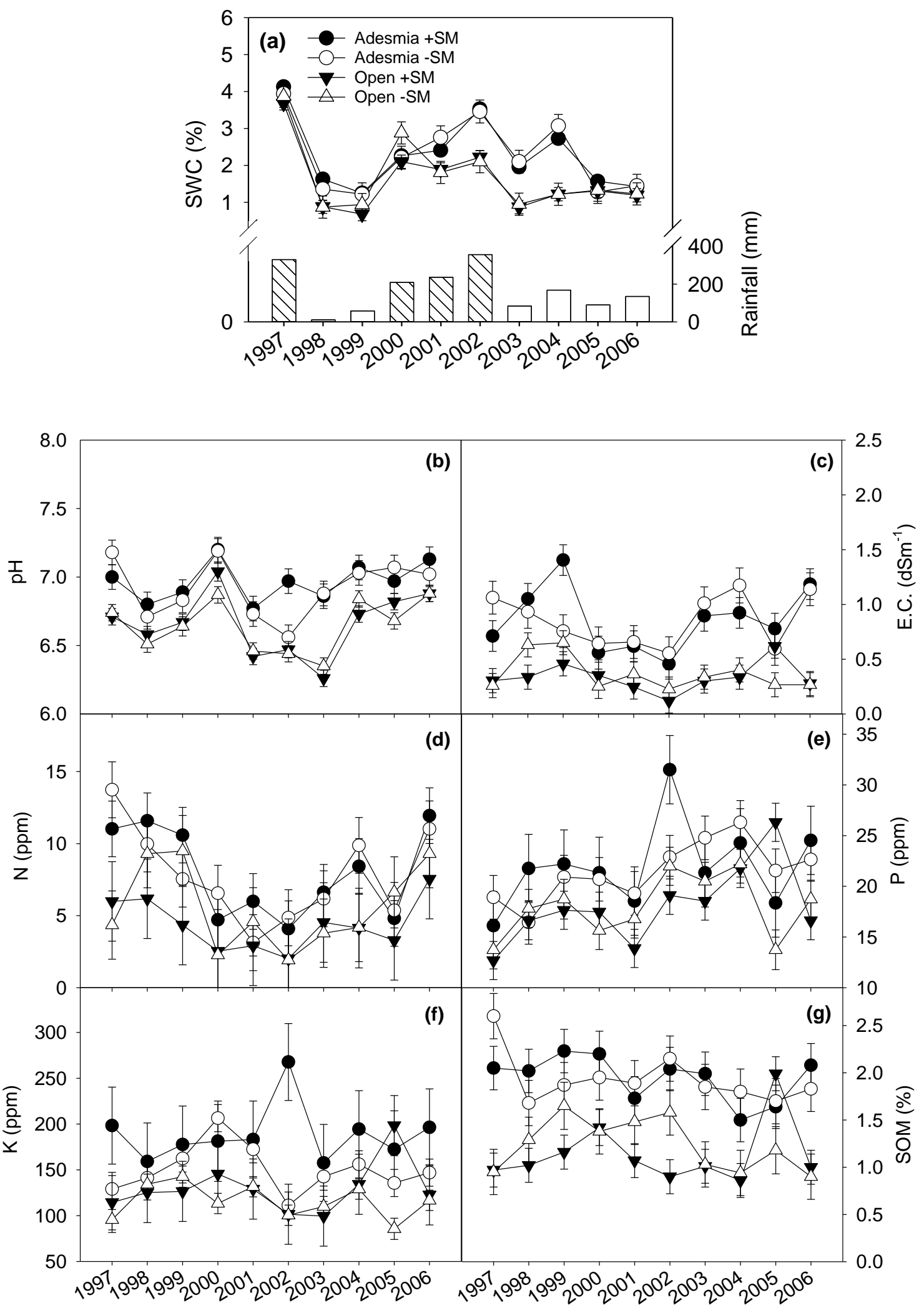
Figure 2

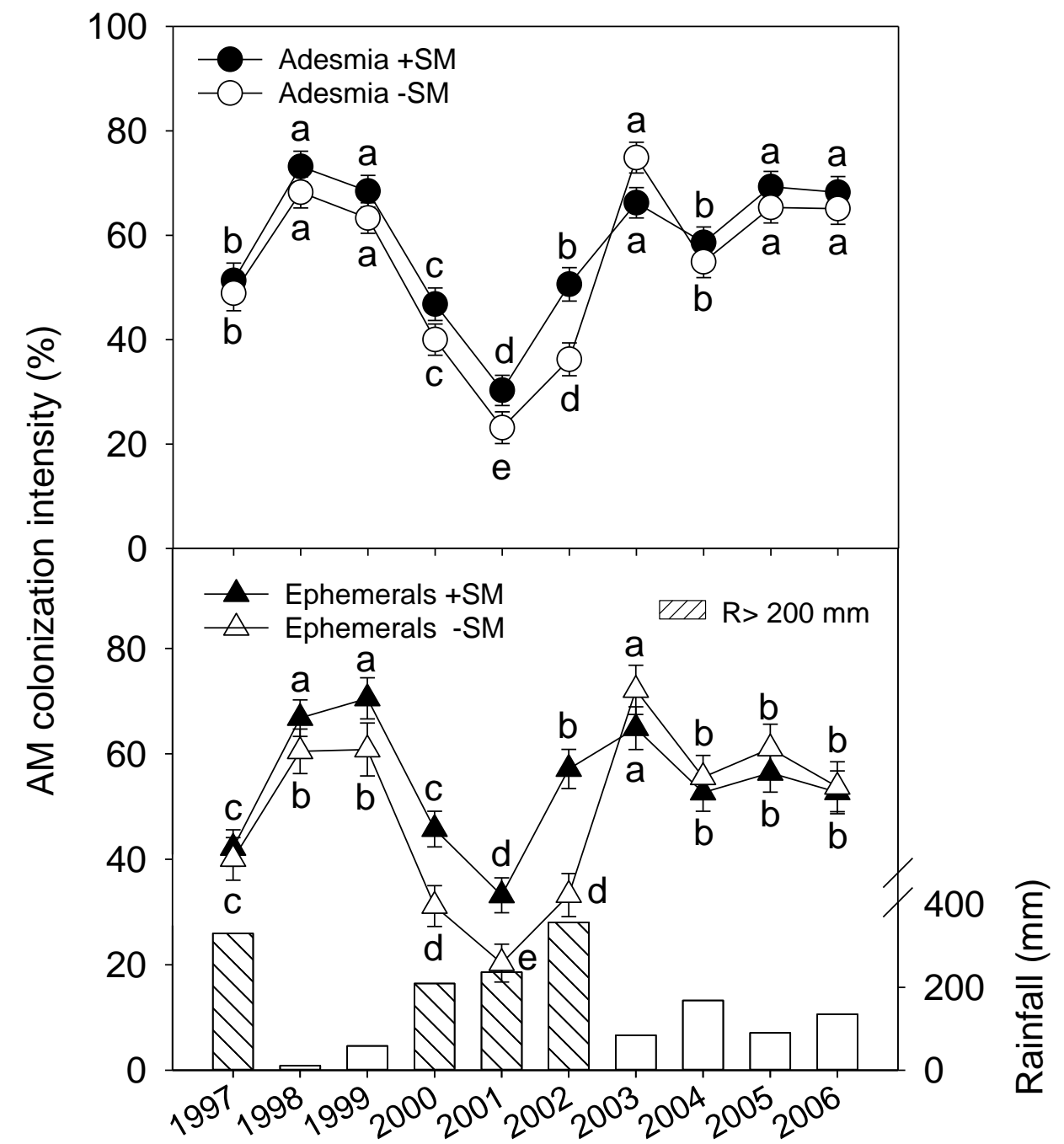

5

6

7

8 
Figure 3

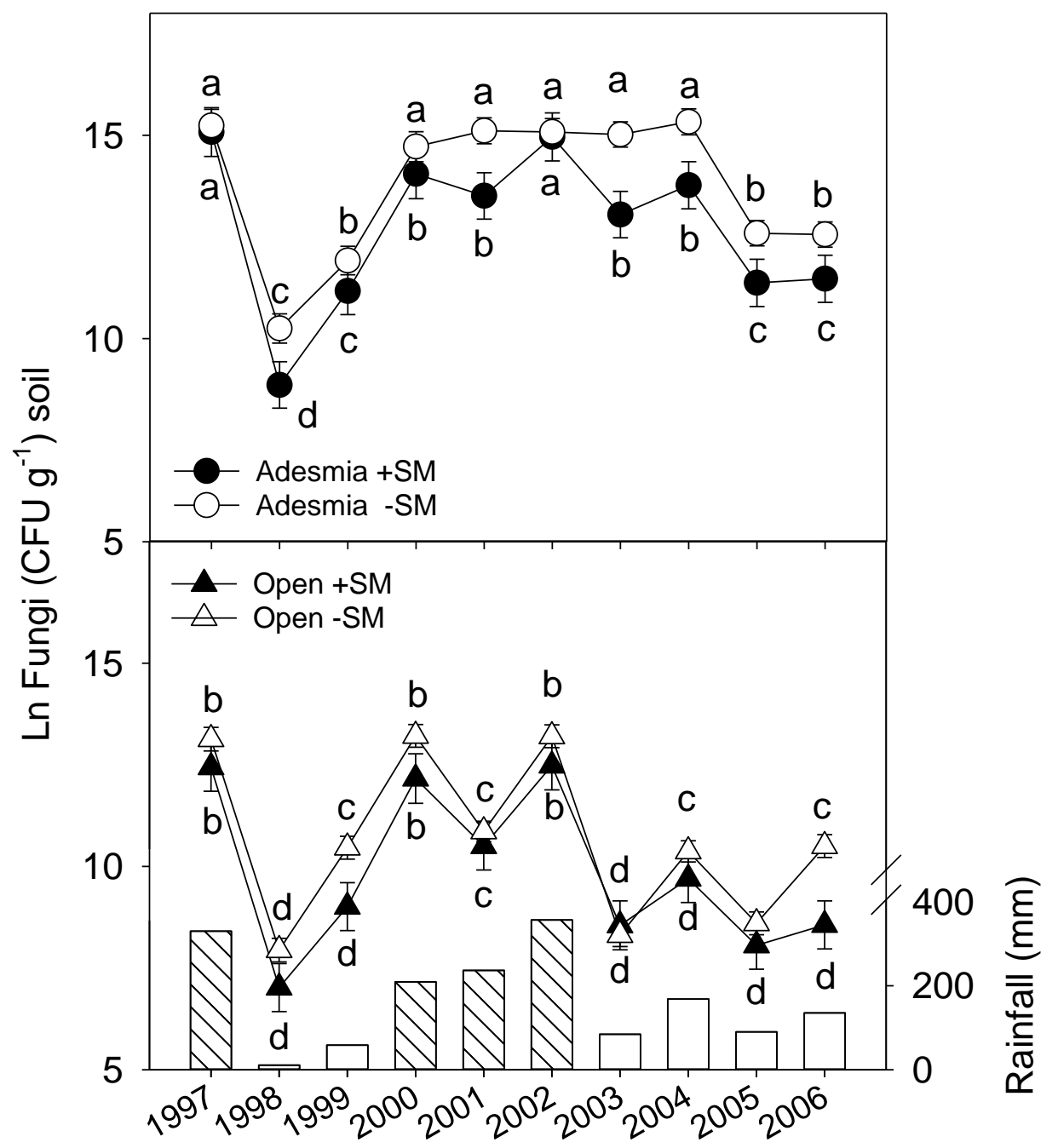

11

12

13

14

15 
Figure 4

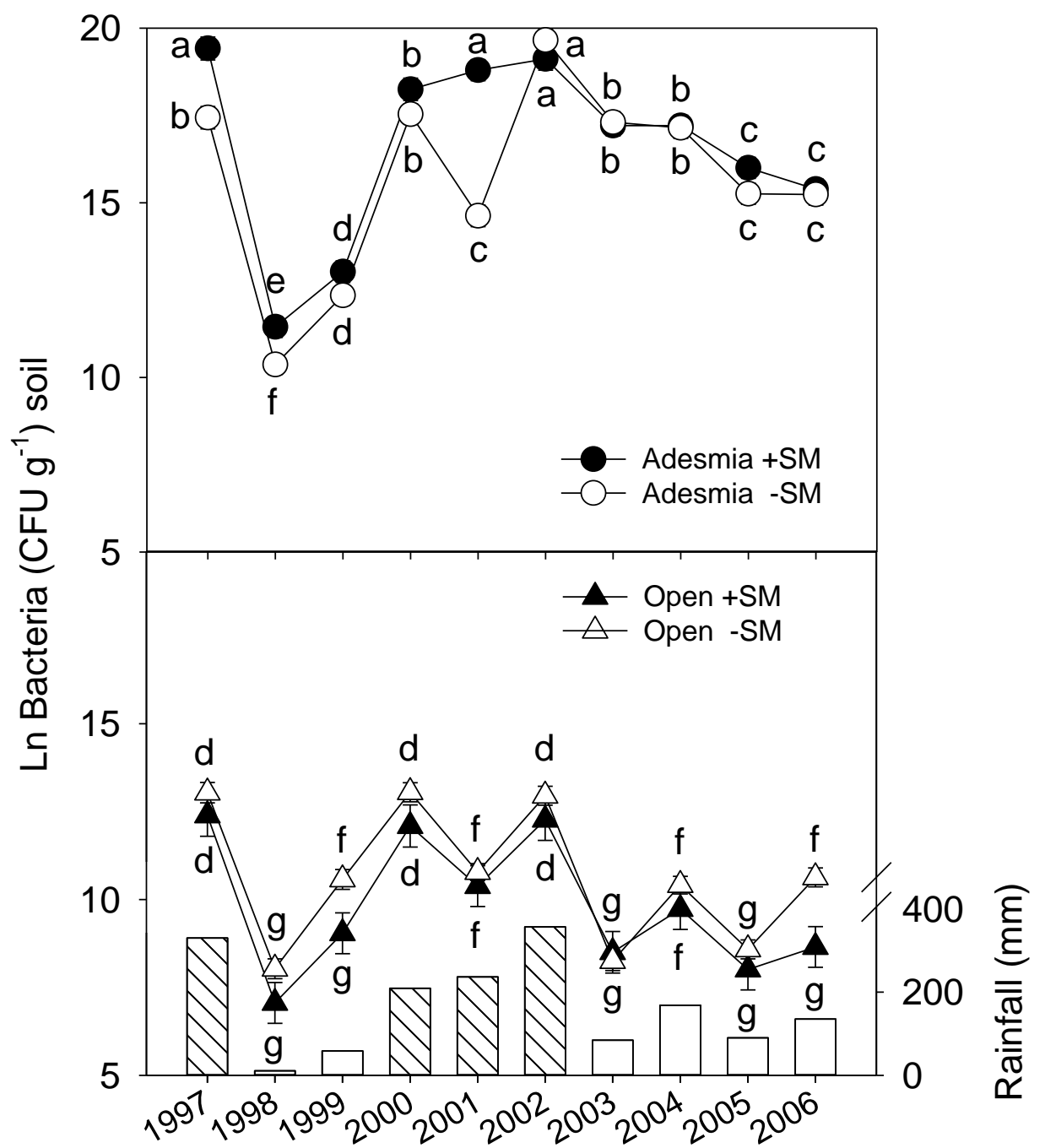

